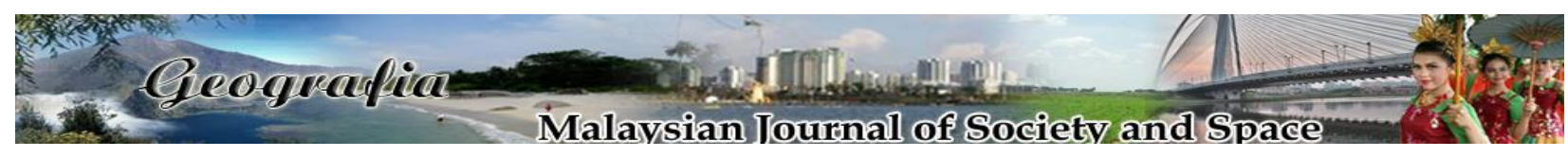

\title{
Head-tail disparity in irrigation management in Sri Lanka: A review of empirical evidence
}

\author{
Yapa L.G.D.S. ${ }^{1,2}$, Ruslan Rainis ${ }^{1}$, Anisah Lee Abdullah ${ }^{1}$, Hemakumara, G.P.T.S. ${ }^{2}$ \\ ${ }^{1}$ Geography Section, School of Humanities, Universiti Sains Malaysia, Penang \\ ${ }^{2}$ Geography Department, University of Ruhuna, Sri Lanka
}

Correspondence: L.G.D.S. Yapa (email: sewwandiyapa87@student.usm.my)

Received: 19 July 2020; Accepted: 22 September 2020; Published: 29 November 2020

\begin{abstract}
Participatory Irrigation Management (PIM) was introduced in the 1990s as a problem-solving mechanism for addressing poor irrigation system performance in many agricultural areas of the world. However, there is some uncertainty as to whether this policy has achieved successful overall irrigation scheme performance in those places where it has been implemented. The emergence of head-tail differences in the water supply along the canal network has frequently resulted in irrigation system failure, causing this issue to become a subject of heated debate among scholars. Sri Lanka is one of the countries that adopted the PIM policy, where it was implemented in 1992. Therefore, this provides the opportunity to find out if head-tail disparity exists in the irrigation schemes of Sri Lanka too, as in other countries. For that reason, this article conducts a review to assess whether a head-tail difference is present or not in Sri Lanka, by determining if the problems and challenges faced by the tail-end farmers are significantly greater compared to those of the farmers in the head reaches. Of the 32 empirical studies on irrigation management done in Sri Lanka, the results of 10 studies suggest a head-tail asymmetry from the socio-economic and technical perspective. This paper identifies the knowledge gap and then provides insights that would help to overcome the existing problems and challenges of head-tail disparity in irrigation management in Sri Lanka.
\end{abstract}

Keywords: dry zone, head-tail disparity, irrigation water supply, knowledge gap, PIM, Sri Lanka

\section{Introduction}

Irrigation has always been an integral part of agriculture, particularly in the Dry Zone, where seasonal water shortage is a regular occurrence. Without the provision of water through irrigation schemes, agriculture cannot be performed because in between the rainy seasons there are usually drought periods (Aheeyar et al., 2012). With regard to the water availability in Sri Lanka, that 
depends largely on the monsoonal rainfall. Yala (April-September) and Maha (October-March) are the two distinct cropping seasons based on the periodic monsoon rainfall (Marambe et al., 2015; Eriyagama et al., 2010). "Maha", which is the wet period in the Dry Zone, is the major cultivation season in Sri Lanka, while "Yala" is the dry period when farmers are always experiencing a water deficit. However, even during the Maha season, scheduled agricultural practices could be disrupted due to sparse or delayed rainfall. Therefore, the need for irrigation management has become a prominent issue among Dry Zone farmers even during the Maha season as they are mainly dependent on rice cultivation that requires plenty of water.

Over the past few decades Sri Lanka has experienced a growing water crisis, which the existing irrigation system has not been able to cope with adequately. To tackle the issues related to the existing agricultural irrigation system, the government intervened to make some institutional reforms and thereby enhance its effectiveness so that the water demand for crop cultivation could be met. Later on, the Sri Lankan government accepted the PIM through a cabinet paper in 1989 and has been implementing it since 1992 as a major national irrigation management policy (Aheeyar et al., 2012; Jinapala et al., 2010). The primary goals of the PIM policy are to reduce the government expenditure on operation and maintenance of irrigation schemes by transferring a part of the responsibilities to the farmers, while at the same time improving the irrigation performance (Aheeyar et al., 2012). Thus, improved irrigation performance would lead to enhanced crop production and bring social unity among farmers. Accordingly, the government allocated financial and other resources directly to the Irrigation Agency for operation and maintenance of the head works and main canals while the operation and maintenance tasks of the distributary canals and field canals became the responsibility of farmer organizations (Aheeyar et al., 2012). This was a good arrangement because irrigation development in Sri Lanka has been an ongoing process since the early 1950s. Gal Oya, Parakrama Samudra, Hurulu Wewa, Nagadeepa, Uda Walawe, Rajanganaya, Accelerated Mahaweli Development Project, Inginimitiya, Kirindi Oya, Uma Oya, Deduru Oya, Yan Oya, and Moragahakanda multipurpose development projects are examples of major irrigation works in Sri Lanka. In addition, Gin Ganga, Kalu Ganga, Nilwala Ganga, Iranaimadu and Weli Oya projects are currently in the implementation stage in Sri Lanka (Aheeyar et al., 2012). Moreover, three different management models were introduced to operate irrigation schemes under the participatory approach in the 1980s. They are Integrated Management of Agricultural Settlement Schemes (INMAS) program, Management of Irrigation Schemes (MANIS) program, Mahaweli Economic Agency (MEA) model, and the Bulk Water Allocation (BWA) program implemented by the Mahaweli Authority of Sri Lanka (Aheeyar et al., 2012). Accordingly, the medium and large irrigation schemes are managed by either the Irrigation Department or Mahaweli Authority of Sri Lanka through PIM, with the aim of improving irrigation performance (Aheeyar et al., 2012).

Numerous empirical studies have been conducted in Sri Lanka since 1992, with focus on the reforms and benefits of PIM at different scheme levels, regardless of head and tail locations (e.g. Upasena \& Abeygunawardena, 1992; Aheeyar \& Smith, 1999; Samad \& Vermillion, 1999; Sakthivadivel et al., 2001; Thiruchelvam, 2010). A somewhat different approach was adopted by Pieris et al. (2004), Jayakody et al. (2005), Wijerathna (2005), Aheeyar and Jayasooriya (2015), and Saumyarathna et al. (2016), who made studies of irrigation performance at the tail-end areas. However, very few recent studies have focused on the head-tail disparity from an economic standpoint (e.g., Shantha \& Ali, 2011; Kumari et al., 2010; Berundharshani \& Munasinghe, 2015). Adopting another approach, Jinapala et al. (2010) conducted a review of the past, present 
and future status of PIM in Sri Lanka, by considering the performance of farmer organizations, joint management committee system, and irrigation management transfer at scheme level. However, there has been no consensus on the head-tail disparity in water availability, which is mainly responsible for irrigation management failure. This article aims to develop a better understanding of the real situation regarding head-tail disparity in irrigation management in Sri Lanka. Understanding the tail-end problems associated with current irrigation management is essential for policymaking in light of the increasing poverty and vulnerabilities that can be caused by them. Similarly, we need to better understand the hurdles faced by tail-end farmers in achieving the same level of performance from the irrigation scheme as the more advantageously placed farmers at the head of the canal. Accordingly, this paper reviews recent studies that focus on the problem of water insecurity at the tail-end of canal irrigation systems and the variations in water supply. The study attempts to analyze the problems in order to understand the head-tail disparity in irrigation management after gathering data from different locations of the country.

\section{Materials and method}

The tail-end farmers' problems and challenges posed by different irrigation schemes were examined based on journal articles, conference papers, and research articles published by universities and agricultural institutions from 1999 to 2018. Studies were limited in geographic scope to the island of Sri Lanka. All available research papers and conference papers in academic databases including Web of Science, Scopus and Google Scholar search engine were reviewed to summarize tail-end farmers' problems and challenges posed by different irrigation schemes in Sri Lanka. Moreover, published "Grey Literature" including conference proceedings and institutional repositories were scrutinized to find out more about empirical evidence in the field. The International Water Management Institute (IWMI) and Hector Kobbekaduwa Agrarian Research and Training Institute (HKARTI) are currently leading institutions that carry out research in the field of agriculture and irrigation water management in Sri Lanka. Therefore, all available research articles published by IWMI and HKARTI since 2001 were referred to for this study.

\section{Evidence of variations in irrigation water supply}

\section{Inadequacy of supply in canal networks}

Inadequacy in water distribution means failure to deliver the full quota of water required for proper growth of the crop. Inadequacy is most likely caused by low water capacity or low water level of the reservoir and poor water management at the farm level. In fact, inadequacy is the main problem associated with the water supply at the tail-end of any irrigation scheme as water availability is unlikely to be adequate at this location as it is sited too far away from the source (Shantha \& Ali, 2011). In Sri Lanka, canal water inadequacy has been observed within a watercourse, along the distributaries, and along the main canal, especially during the "Yala season", when water shortage is acute. However, the seasonal water allocation plan is prepared for each season based on water availability, land use patterns, and the crop water requirement, by referring to past experience, and other indices such as seepage and percolation rates. The method 
of water management in an irrigation scheme is either demand-oriented or supply oriented, and this is determined based on the active storage of the reservoir (Jayakody et al., 2005). Moreover, a few studies show that even if a carefully estimated volume of water is released into the distributary canals, allowing all the farmers to do their cultivation according to the cropping calendar, then all farmers will probably not receive their fair of share of water through the field canals (Pieris et al., 2004). It is well proven that field canal water allocation will not be fair to all users, due to poor infrastructure facilities, absence of social cohesion, and weak organizational capacities (Paranage, 2018). Furthermore, inadequate maintenance and careless operation will cause the irrigation infrastructure to deteriorate, and this will result in poor irrigation efficiency (Abayawardana et al., 2006). Lack of communication and coordination between the farmers and farmers' representatives could also affect and aggravate this problem at the tail-end. At times, canal water inadequacy causes delays in the land preparation. If the water supply is limited, the water users at the tail-end will not be able to complete their land preparation and at other times they may not receive prior information about the water supply schedule (Molle et al., 2008). Furthermore, some farmers may occasionally rotate water on an ad-hoc basis as there is no mechanism to monitor the field canal water, resulting in inadequate supply of water for downstream farmers (Berundharshani \& Munasinghe, 2015).

Additionally, several studies have revealed that a number of problems and challenges are faced by the tail-end farmers due to inadequate field drainage. Income inequality and poverty at the tail-end area is one of the unresolved issues in large scale irrigation commands, and these can be attributed to an inadequate amount of irrigation water that is also unevenly distributed (Thiruchelvam, 2010; Shantha \& Ali, 2011). The income level of each farmer is determined by the amount of water available for his fields, the condition of the irrigation infrastructure, diversification of cropping patterns, and suitability of the land for the crop under cultivation. Kumari et al. (2010) and Wijerathna (2005) point out that a high incidence of poverty can be seen at the tail end of the Minipe irrigation scheme and Uda Walawe Left Bank irrigation project area, compared to their head and middle reaches. Paranage (2018) further notes that the cultivation of other field crops in the tail end tracts results in income fluctuation and low profitability as the market for alternative crops is uncertain. According to Shantha and Ali (2011), the annual income disparity between the head and tail farmers is very high in Mahaweli System B compared with the overall national and rural levels. It represented a ratio of 1:0.63. Furthermore, this study indicated that the Sen Poverty Index for tail-enders is double (0.477) that of head-enders with 31.12 percent of tail-end farmers falling below the national poverty line owing to the poor performance of their agribusinesses. Moreover, Kumari et al. (2010) show that a higher Gini coefficient (GC) value of 0.41 and low cropping intensity (CI) of 0.51 is recorded for the tail reaches of the Minipe major irrigation scheme than for its head reaches $(\mathrm{GC}=0.34, \mathrm{CI}=0.99)$ as a result of reduced access to water. Another finding, which is in marked contrast, reveals that the mean net revenue per acre from other field crops in the tail-end areas of Huruluwewa and Minipe major irrigation schemes is higher than that of the head-end areas where paddy cultivation is mostly practiced (Berundharshani \& Munasinghe, 2015; Kumari et al., 2010).

These issues have been further aggravated by the emerging environmental problems at the downstream section of the canals. Accordingly, secondary soil salinization has occurred fully or at least in patches in the irrigated areas, where canal operation and maintenance have been very poor (Aheeyar, 1999; Thiruchelvam \& Pathmarajah, 1999). Thiruchelvam and Pathmarajah (1999) reported severe salinity conditions at Nochchiyagama in the Mahaweli H Zone owing to 
the dry climate, poor drainage practices, waterlogging, inefficient irrigation management, and use of drainage water for irrigation. Low productivity, soil degradation, rise in salinity and increased cost of controlling salinity are the major problems faced by the tail-end farmers (Aheeyar, 1999; Thiruchelvam \& Pathmarajah, 1999). Aheeyar and Jayasooriya (2015) have also reported that newly cultivated lands in the Walawe Left Bank have been abandoned fully or partially as a result of the build-up of salinity patches. Also, Silva (2004) has recorded that some reservoirs in the Dry Zone, for example, Nachchaduwa, Tissawewa, Minneriya, Parakrama Samudra, Kalawewa, and Rajangana have exceeded the threshold value for electrical conductivity and salinity, which ranged from approximately $100 \mathrm{mS} \mathrm{cm}$-1 to $450 \mathrm{mS} \mathrm{cm}^{-1}$, especially at the end of the Southwest monsoon season (August-September).

\section{Unreliability of water supply}

Unreliability of water supply is due to failure to ensure water delivery as per the seasonal water allocation schedule, and this has the effect of discouraging farmers from engaging in cropping activities. However, several studies have revealed that farmers' experience of water shortage at tail-ends was particularly severe in irrigation commands during the Yala season (Saumyarathna et al., 2016; Aheeyar et al., 2012; Thiruchelvam, 2005). A study conducted by Sakthivadivel et al. (2001) on the right bank of the Kirindi Oya project area highlights that the tail-end farmers faced water scarcity at all stages of crop growth, culminating in a severe water-deficit situation during the Yala season. Pieris et al. (2004) pointed out that the tail-end farmers at the Right Bank of Uda Walawe too faced a severe water deficit, as a result of which a considerable number of agricultural farms were left uncultivated, which led to the reallocation of water to the newly developed area on the Left Bank of Uda Walawe. Farm productivity and annual cropping intensity depend on the irrigation facilities and the location of the farm along the course of the canal irrigation system. The crops are stressed to a considerable extent during water scarcity and the outcome of poor long term supply is an increase in cultivable lands that lie fallow, leading to lower productivity and poor performance in the tail reaches (Kumari et al., 2010; Sakthivadivel et al., 2001).

Low productivity, low cropping intensity, and low income mean that there is a high level of uncertainty and income fluctuation in their farming (Shantha \& Ali, 2011). As well, Aheeyar et al. (2012) show that 20 percent of farmers in the Mahaweli B Zone suffer from irregular water supply due to the poor condition of the irrigation infrastructure. Moreover, a few studies show that uncertainty of water availability at the land preparation stage is one of the daunting challenges faced by the tail-end farmers of certain other irrigation schemes in Sri Lanka. During the land preparation period, the farmers in the head reaches are never in a hurry to follow a prescribed schedule as they always have enough water, but the tail-end farmers get late for land preparation due to inadequate flow or lack of plowing equipment (Molle et al., 2008; Pieris et al., 2004). Besides, lack of cooperation among farmers has made it difficult to follow the seasonal water schedule closely and perform all the actions at the right time; this has resulted in the tailend farmers being affected by the actions of the head-end farmers. It was revealed that some farmer organizations at the tail-end had failed badly at irrigation management from the very beginning of the season. Further, as farmers have no mechanism to monitor the flow of field canal water, they just rotate water on an ad-hoc basis without considering other canals (Berundharshani \& Munasinghe, 2015). Thus, dissatisfaction with the performance of farmer organizations is high among the tail-enders at times. 


\section{Inefficiency and inequity in irrigation water distribution}

Although Participatory Irrigation Management in Sri Lanka has been implemented since 1992, still the overall performance of a majority of the irrigation projects is lower than what had been anticipated in terms of agricultural productivity and reduction of government expenditure on operation and maintenance. The spatial inconsistency in irrigation supply has led to agricultural productivity differences between the head and tail reaches. Aheeyar and Smith (1999) state that no significant differences in water distribution have been observed between the head and tail parts of the Rajanganaya and Mee Oya irrigation schemes after PIM was introduced. This means the distribution of irrigation water among users is in a fair and just manner. In contrast, several studies have shown that the tail-end farmers are always exposed to a higher level of risk and uncertainty because they demonstrably receive a smaller share of water compared to the headend farmers (Shantha \& Ali, 2013; Pieris et al., 2004). As head-end farmers have immediate access to the source compared to those downstream, they tend to use more than their fair share of water unless water quotas are strictly enforced (Paranage, 2018; Aheeyar et al., 2012; Aida, 2019; Wijerathna, 2005; Pieris et al., 2004). Several studies on irrigation management have pointed out that farmers at the head-end tend to over-irrigate their fields, without considering the tail-end commands, and thereby violate the rules. Moreover, Pieris et al. (2004) observe that the lands at the head reaches of the field canal receive almost 35 percent more water than the command area allocation. Further, it has been proved that much of that water flows into the drainage canal after passing through head-end allotments without being utilized for cultivation. Naturally, this adversely affects the tail-end farmers. Pieris et al. (2004) state that tail-end farmers are upset and annoyed by the action of the head-end farmers who cultivate their paddy lands by using water directly from the distributary canal and also from the drainage canal.

Cropping intensity and crop diversification depend on irrigation efficiency. While the actual discharge of the distributary canals is sufficient to irrigate the tail-end command area, due to the uneven distribution of field canal water it is not possible to feed the entire area equitably (Pieris et al., 2004). Furthermore, increasing the extent of the irrigated area and planting crops of their choice at the tail-end are restricted. Unlike head-end farmers, the tail-end farmers cannot cultivate high water-consuming crops like paddy, so they are compelled to cultivate alternative crops like banana, beans, vegetables and the like that have a low water requirement (Kumari et al., 2010; Thiruchelvam, 2005). Therefore, most of the farmers at the tail-end of the right bank of the Uda Walawe irrigation scheme have adopted the "Chena" type cultivation method (Shifting cultivation method) because of water inadequacy (Pieris et al., 2004). Even though "on" and "off" mode of water distribution with rotation pattern along the canals has been introduced to overcome the head-tail inequity problem (Sakthivadivel et al., 2001), sometimes the farmers at the tail-end often fail to get their due share of water due to the canal water being tapped illegally. Illegal drawing of water and the resulting disharmony among farmers are the most vexing problems faced by tail-end water users. Apart from conveyance losses and technical constraints, illegal water tapping causes inequity in water distribution, leading to conflicts among farmers (Aida, 2019). Saumyarathna et al. (2016) and Aheeyar et al. (2012) have pointed out that competition for limited water supplies and conflicts in sharing water among different water users was a common issue faced in the management of the present irrigation system. Saumyarathna et al. (2016) disclose that conflicts between farmers inevitably occurred when some of them tried to draw more water than their allotted share, especially during the Yala season. Poor attitudes of farmers, weakness of regulations governing existing land and water rights, non-implementation 
of existing laws, encroachments, and inadequate institutional arrangements were the contributing factors that led to water conflict in the Hakwatuna Oya irrigation scheme, as pointed out by Saumyarathna et al. (2016).

\section{Discussion: The knowledge gap}

The emergence of head-tail differences in the water supply along the canal network, resulting in irrigation management failure, is still the subject of much debate among scholars in many countries. Therefore, there has been a growing emphasis on linking water policy with water security in irrigation management. In this sense, are present studies adequate to make an effective assessment of head-tail differences in irrigation management in Sri Lanka? The general consensus of opinion is that the PIM is a win-win solution to enhance the water efficiency and agricultural productivity of a country. Accepting this viewpoint, many scholars have tried to focus on the overall successes at the scheme level rather than looking for its failures at the field level. Some authors simply say irrigation efficiency has increased after the implementation of PIM. Does this provide a real picture of the scheme's performance at irrigation management? For example, water use performance could be high or improved but the agricultural performance might be low or in a declined state. While many studies have turned up mixed results about present irrigation management in Sri Lanka, there is no consensus about tail-end irrigation performance. Many studies conducted across the world have measured water delivery performance using various indicators (Unal et al., 2003; Gorantiwar et al., 2006), but hardly any analytical methods have been applied in Sri Lankan studies. While several studies have pointed out that water adequacy, reliability, equity and efficiency (or the lack thereof) determined the head-tail performance of a scheme, only a few have shown how these factors work to increase the head-tail differences in terms of productivity and income inequality. Therefore, considerable research efforts continue to be made to identify the illegal water tapping hotspots and high water consumption locations along the distributary canal since water supply for the tail-end needs to be better managed to ensure water security for all cultivators. It is more desirable to identify the exact causes of changes in irrigation management at the block level rather than assessing them at the scheme level. This would prove more useful to the authorities to improve the performance of irrigation at the block level. Examining the internal and external factors affecting water supply performance at the tail-ends is very critical to identify the unique potential of each location at the different schemes. Moreover, it is unlikely that the authorities would develop the present irrigation system further without identifying the existing problems at the tail-end areas.

About 600,000 ha of land are under irrigation in Sri Lanka, of which over 80 percent is in the Dry Zone; about 400,000 ha come under major schemes in both the Dry Zone and Wet Zone (Abayawardana et al., 2006). Despite the large area under cultivation, no analysis of the performance indicators such as irrigation productivity, cropping intensity, water duty, and land productivity of different tail-end locations appears to have been done. Further, the selection of methodology, sample size, and research findings of some of the existing studies are also not at a satisfactory level so it is difficult to accept their findings. Many authors have studied the tail-end problems at the field level through various approaches such as using questionnaires, field observation, and informal discussions. Therefore, to expand the research on tail-end farming it is essential to adopt a multidisciplinary approach that actively involves field expertise. Furthermore, understanding the role of tail-end farmers in food security is important, as this will 
do much to ensure they acquire the right and the means to access canal water as readily as the head-end farmers. Observational and anecdotal evidence is not enough to assess water supply variation in different locations. Although many international studies have used Remote Sensing (RS) and Geographic Information System (GIS) to estimate the irrigation efficiency and agricultural productivity in irrigation management (see Ray et al., 2002; Kharrou et al., 2013; Akbari, 2007), most studies conducted in Sri Lanka have not applied such high accuracy mapping techniques to assess water delivery disparities. While many international scholars have used conceptual and analytical frameworks to assess agricultural productivity and water delivery performance in different irrigation schemes (see Gorantiwar et al., 2006; Dawande et al., 2013), much less interest has been shown in applying such frameworks to the Sri Lankan studies.

Few Sri Lankan researchers have focused on farmers' participation in irrigation management from different perspectives as is the practice in other countries. Multiple factors have influenced the performance gains or setbacks related to water use. Irrigation water management procedure, farmer participation, structural intervention, and resource mobilization are the significant features affecting a scheme's overall performance. Therefore, a comprehensive understanding of these features of management intervention is vital to visualize the real picture of irrigation management performance between the head reaches and tail-ends. It is important to gain a better understanding of how spatial and non-spatial factors affect the participation of tail-end farmers in irrigation management. In the water allocation plan for example, delivering water adequately to all farmers is the main objective, as without that the cultivation plans will never be a success. Therefore, it is essential to find out whether the tailenders receive their fair share of water, and if that is not the case, it will be necessary to find effective remedies to enhance PIM performance at the scheme level.

\section{Conclusion}

No research studies on the head-tail disparity in irrigation management were done from 1992 to 2004 but several studies have been conducted since 2005. Although the PIM attempts to increase the water distribution efficiency, adequacy, reliability, and timeliness through scheduled water issue plans, the irrigation and agricultural performance gap between the head reaches and tailends of the different schemes have often been rather wide, resulting in irrigation management failure. Based on the findings of previous studies, it was revealed that the water distribution inadequacy, unreliability, inequality, and inefficiency increased in proportion to the distance from the head of the irrigation canal. The differences in the water supply have been recorded at different locations, such as within a watercourse, along the distributaries, and the main canal. Consequently, the problem of water deficit, low irrigation intensity, poor agriculture intensification, widespread adoption of low water consuming varieties, and impoverished livelihoods are common at the tail-end of the canal network. Only a few studies have explained how water supply variation acts to increase the head-tail differences in terms of lower productivity and income inequality. On the other hand, lack of water and erratic water supply are the major obstacles to the development of irrigated agriculture in the country, which in turn can lead to the dynamic of economic and social differentiation between local communities. Furthermore, many studies reveal that the present irrigation management system in Sri Lanka yields mixed results, as there is no consensus regarding its effect on head-tail disparity and agricultural productivity of the country. Doubts are also expressed about its sustainability. 
Another shortcoming is that the actual amount of water distributed along the field canals is unknown, resulting in farmer organizations not having a mechanism to monitor the water flow at the field canal level. Therefore, pursuing research efforts at the unit level is vital to understand the prevailing situation fully. In fact, a few authors have studied tail-end problems at the irrigation block levels through various approaches such as questionnaires, field observation, and informal discussions. However, observational and anecdotal evidence is not enough to assess the impact of water supply variation at different locations. Therefore, this study concludes that there is a need to expand research efforts in this field, by following appropriate conceptual and analytical frameworks; this would require the active involvement of field expertise and the adoption of a multidisciplinary approach.

\section{References}

Abayawardana, S., Marikar, F., Wijerathna, D., \& Gichuki, F. (2006). Development strategy for the irrigation sector of Sri Lanka 2006-2016. Colombo, Sri Lanka, International Water Management Institute. Retrieved from https://publications.iwmi.org/pdf/H040801.pdf

Aheeyar, M. M. (2006). Willingness to pay for improved irrigation services in Mahaweli system $\mathrm{H}$ [Paper presentation]. 32nd WEDC International Conference on sustainable development of water resources, water supply and environmental sanitation, Colombo, Sri Lanka (pp.227-230). Loughborough University Repository. Retrieved from https://repository.lboro.ac.uk/articles/Willingness_to_pay_for_improved_irrigation_servi ces_in_Mahaweli_system_H/9596882/1

Aheeyar, M. M. M., \& Jayasooriya, H. J. C. (2015). Impacts and Lessons of Uda-Walawe Left Bank Irrigation Upgrading and Extension Project for Water Resources Management (Research Report No:176). Colombo, Sri Lanka, Hector Kobbekaduwa Agrarian Research and Training Institute. Retrieved from http://www.harti.gov.lk/images/ download/reasearch_report/new1/176.pdf

Aheeyar, M. M. M., \& Smith, L. E. D. (1999). The impact of farmer participation on water distribution performance in two irrigation schemes in Sri Lanka. Sri Lanka Journal of Social Sciences, 22(1\&2), 27-43

Aheeyar, M. M. M., Padmajani, M. T. \& Bandara, M. A. C. S. (2012). Farmer participation in irrigation system management: achievements and drawbacks. Colombo, Sri Lanka, Hector Kobbekaduwa Agrarian Research and Training Institute. Retrieved from http://www.harti.gov.lk/images/reports/farmer_participation_in_irrigation_system_mana gement_achievements_and_drawbacks.pdf

Aida, T. (2019). Social capital as an instrument for common pool resource management: a case study of irrigation management in Sri Lanka. Oxford Economic Papers, 71(4), 952-978.

Akbari, M., Toomanian, N., Droogers, P., Bastiaanssen, W., \& Gieske, A. (2007). Monitoring irrigation performance in Esfahan, Iran, using NOAA satellite imagery. Agricultural water management, 88(1-3), 99-109.

Berundharshani, T., \& Munasinghe, D. S. (2015, December). Drought Resilient Farming System through Crop Diversification: the Case of Huruluwewa. In Proceedings of the 6th annual National Building Research Organization Symposium on Innovations for Resilient Environment (pp. 35-40). Colombo, Sri Lanka. 
Dawande, M., Gavirneni, S., Mehrotra, M., \& Mookerjee, V. (2013). Efficient distribution of water between head-reach and tail-end farms in developing countries. Manufacturing \& Service Operations Management, 15(2), 221-238.

Eriyagama, N., \& Smakhtin, V. (2010, June). Observed and projected climatic changes, their impacts and adaptation options for Sri Lanka: a review [Paper presentation]. In Proceedings of the National Conference on Water, Food Security and Climate Change in Sri Lanka (pp. 99-117). Colombo, Sri Lanka.

Gorantiwar, S. D., Smout, I. K., \& Vairavamoorthy, K. (2006). Performance-based optimization of land and water resources within irrigation schemes. I: Method. Journal of irrigation and drainage engineering, 132(4), 332-340.

Jayakody, P., Molle, F., \& Najim, M. M. M. (2005, October). Deviation of planned water demand from actual on farm water usage and suggestions for improvements: a case study from Uda Walawe irrigation scheme, Sri Lanka [Paper presentation]. Water Professionals' Day Symposium. University of Kelaniya Digital Repository. Retrieved from http://repository.kln.ac.lk/handle /123456789/3897.

Jinapala, K., Premadasa, L., Somaratne, P. G., \& Samad, M. (2010). Managing irrigation jointly with farmers: history, present status and future: review of participatory irrigation management in Sri Lanka [Paper presentation]. In Proceedings of the National Conference on Water, Food Security and Climate Change in Sri Lanka (pp. 35-63). Colombo, Sri Lanka

Kharrou, M. H., Le Page, M., Chehbouni, A., Simonneaux, V., Er-Raki, S., Jarlan, L. \& Chehbouni, G. (2013). Assessment of equity and adequacy of water delivery in irrigation systems using remote sensing-based indicators in semi-arid region, Morocco. Water resources management, 27(13), 4697-4714.

Kumari, B. A. P., Thiruchelvam, S., Dissanayake, K. M. H., \& Lasantha, T. (2010). Crop diversification and income inequality in irrigation systems: The case of Minipe. Tropical Agricultural Research, 21(3), 308-320.

Marambe, B., Punyawardena, R., Silva, P., Premalal, S., Rathnabharathie, V., Kekulandala, B., \& Howden, M. (2015). Climate, climate risk, and food security in Sri Lanka: the need for strengthening adaptation strategies. In: Leal Filho W. (eds), Handbook of Climate Change Adaptation (pp1759-1789). Springer.

Molle, F., Jayakody, P., Ariyaratne, R., \& Somatilake, H. S. (2008). Irrigation versus hydropower: sectoral conflicts in southern Sri Lanka. Water Policy, 10(S1), 37-50.

Paranage, K. (2018). Understanding the relationship between water infrastructure and sociopolitical configurations: a case study from Sri Lanka. Water, 10(10), 1402.

Pieris, W. R., Dayawansa, N. D. K., Mole, F., \& De Silva, W. P. R. P. (2004). Tertiary level irrigation water management practices at tail end: a case study from Uda Walawe irrigation scheme. Tropical Agricultural Research, 16, 181-192.

Ray, S. S., Dadhwal, V. K., \& Navalgund, R. R. (2002). Performance evaluation of an irrigation command area using remote sensing: a case study of Mahi command, Gujarat, India. Agricultural water management, 56(2), 81-91.

Sakthivadivel, R., Loeve, R., Amarasinghe, U. A., \& Hemakumara, M. (2001). Water scarcity and managing seasonal water crisis: lessons from the Kirindi Oya Project in Sri Lanka. Colombo, Sri Lanka, International Water Management Institute. Retrieved from http://www.iwmi.cgiar.org/Publications/IWMI_Research_Reports/PDF/pub055/Report55 .pdf 
Samad, M., \& Vermillion, D. (1999). An assessment of the impact of participatory irrigation management in Sri Lanka. International Journal of Water Resources Development, 15(12), 219-240.

Saumyarathna, N. G. R., Gunawardena, E. R. N., \& Dayawansa, N. D. K. (2016). Water conflicts among different water users and uses in the Hakwatuna Oya watershed in the Deduru Oya basin, Sri Lanka. Tropical Agricultural Research, 28(1), 38-49.

Silva, E. I. L. (2004). Quality of irrigation water in Sri Lanka-status and trends. Asian journal of water, environment and pollution, 1(1,2), 5-12.

Shantha, A. A., \& Ali, B. A. (2011, November). The impact of uneven allocation of irrigation water on dynamics of agribusiness and income inequality: The case of Mahaweli Development Project, Sri Lanka [Paper presentation]. In Proceedings of International Conference on Business Management (pp.148-155). Colombo, Sri Lanka .

Shantha, A. A., \& Ali, B. A. (2013, April). Income inequality among major irrigation schemes in Sri Lanka: Gini decomposition approach [Paper presentation]. In Proceedings of the Kuala Lumpur International Business, Economic and Law Conference (pp. 118-127). Kuala Lumpur, Malaysia.

Thiruchelvam, S. (2005). Agricultural production efficiency of bethma cultivation in Mahaweli System H. Sri Lankan Journal of Agricultural Economics, 7(1), 1-20.

Thiruchelvam, S. (2010, June). Enhancement of capacity of farmer organizations for sustainable irrigation systems in Anuradhapura and Kurunegala Districts. In Proceedings of the National Conference on Water, Food Security and Climate Change in Sri Lanka (pp. 717). Colombo, Sri Lanka.

Thiruchelvam, S., \& Pathmarajah, S. (1999). Economic analysis of salinity problems in the Mahaweli River system H irrigation scheme in Sri Lanka. Singapore, Economy and Environment Program for Southeast Asia. Retrieved from https://idl-bncidrc.dspacedirect.org/bitstream/handle/ 10625/27816/114522.pdf?sequence $=11$

Unal, H. B., \& Asik, S. \& Avci, M. \& Yasar, S. \& Akkuzu, E. (2004). Performance of water delivery system at tertiary canal level: a case study of the Menemen Left Bank Irrigation System, Gediz Basin, Turkey. Agricultural water management, 65(3), 155-171.

Upasena, J., \& Abeygunawardena, P. (1992). Determinants of farmer participation in irrigation management: the case of Kimbulwana Oya scheme. Tropical Agricultural Research, 4, 271-283.

Wijerathna, D. (2005, August). Spatial dimensions of poverty within an irrigated agricultural setting: The case of Uda Walawe Left Bank Irrigation Development Project [Paper presentation]. In Silva R.P.D. Proceedings of the Second National Symposium on GeoInformatics (pp 13-25). Colombo, Sri Lanka. 